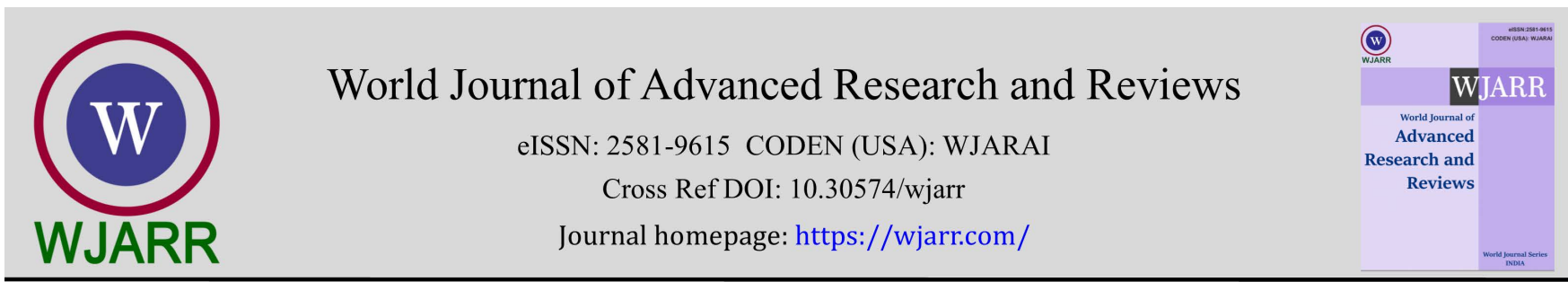

(RESEARCH ARTICLE)

Check for updates

\title{
Improvement yield of sweet corn (Zea mays Saccharata (Sturt.) bailey using arbuscular mycorrhiza fungi (AMF) and cow manure fertilizer (CMF) on ultisol
}

Halim 1, ${ }^{*}$, Laode Sabaruddin ${ }^{1}$, La Ode Santiadji Bande ${ }^{2}$, Yulius Bara Pasolon ${ }^{3}$, Fransiscus Suramas Rembon ${ }^{3}$ and Sahta Ginting 3

${ }^{1}$ Department of Agrotechnology, Faculty of Agriculture, Halu Oleo University, Southeast Sulawesi, Kendari, Indonesia. ${ }^{2}$ Department of Plant Protection, Faculty of Agriculture, Halu Oleo University, Southeast Sulawesi, Kendari, Indonesia. ${ }^{3}$ Department of Soil Science, Faculty of Agriculture, Halu Oleo University, Southeast Sulawesi, Kendari, Indonesia.

World Journal of Advanced Research and Reviews, 2021, 09(03), 304-308

Publication history: Received on 14 February 2021; revised on 17 March 2021; accepted on 20 March 2021

Article DOI: https://doi.org/10.30574/wjarr.2021.9.3.0108

\begin{abstract}
This study aims to determine the effectiveness of arbuscular mycorrhiza fungi and cow manure to yield of sweet corn on Ultisol. This research was conducted using a randomized block design (RCBD) in a factorial pattern. The first factor is arbuscular mycorrhizal fungi (AMF) which consists of four levels, namely without AMF (A0), AMF $5 \mathrm{~g} / \mathrm{planting}$ hole (A1), AMF $10 \mathrm{~g} /$ planting hole (A2), AMF $15 \mathrm{~g} /$ planting hole (A3). The second factor is cow manure fertilizer (CMF) consisting of three levels, namely without CMF (B0), CMF 5 tons ha-1 (B1), CMF 10 tons ha-1 (B2). The treatment applied consisted of 12 treatment combinations which were repeated in 3 replications, so that there were 36 experimental units. The observed variables were: weight of cob with cob, weight of cob without cob, cob length, ear diameter, number of rows of seeds and crop production (ton ha-1). The results showed that the highest average weight cob with husk was obtained in a combination treatment of AMF $10 \mathrm{~g} /$ planting hole and without CMF (A2B0) as $289.2 \mathrm{~g}$. The highest average corn crop productivity was obtained in the combination of treatment without AMF and CMF 5 tons ha-1 (A0B1) as 8.52 tons ha-1.
\end{abstract}

Keywords: Sweet corn; Arbuscular mycorrhizal fungi; Cow manure fertilizer; Ultisol

\section{Introduction}

Sweet corn is a food plant that is very beneficial for humans for a variety of basic needs, industrial raw materials and animal feed. Sweet corn is a horticultural crop that has high economic value, because it can be cultivated every planting season with a relatively short production life when compared to other types of corn. According to [1]when a thumbnail is pressed into a kernel, a milky liquid should emerge indicating the crop is ready for harvest. Sweet corn food products can be processed in the form of fresh preparations such as boiled corn, cakes, chips, corn pudding, corn pancakes and other processed corn products. Nuryadin et al. [2] reported that's sweet corn is an agricultural commodity that is very popular with the community because it contains a lot of nutrients and has economic value. According to [3], sweet corn has economic value in seeds, leaves, stems, panicles and cobs that can be used in a variety of food products and byproducts. Result research Siyuan et al. [4], that's corn nutrients and phytochemicals include vitamins (A, B, E, and K), minerals (Mg, P, and $\mathrm{K}$ ), phenolic acids (ferulic acid, coumaric acid, and syringic acid), carotenoids and flavonoids (anthocyanins), and dietary fiber.

Continuous uptake of the same nutrients from the soil and excessive application of inorganic fertilizers cause environmental pollution, decreased land productivity, and land degradation or decreased soil fertility which results in

${ }^{*}$ Corresponding author: Halim

Department of Agrotechnology, Faculty of Agriculture, Halu Oleo University, Southeast Sulawesi, Kendari, Indonesia.

Copyright (C) 2021 Author(s) retain the copyright of this article. This article is published under the terms of the Creative Commons Attribution Liscense 4.0. 
lower crop production. According to [5], the productivity of sweet corn is currently still low due to the lack of farmers' attention in utilizing agricultural land, cultivation techniques that have not been maximized, and fertile lands that are converted to industrial plants and settlements. An effort to develop sweet corn needs to be sought alternatives, one of which is the utilization of Ultisol soil. Ultisol soil is a land with low soil fertility, acid reaction with soil pH below 5.5 and low macro-nutrient content of N, P, K, Ca and Mg and high solubility of $\mathrm{Al}$ and Fe that can poison plant growth [6].

Increased productivity of sweet corn plants in Ultisol can be done through the application of mycorrhiza fungi and organic fertilizer from cow manure. The mycorrhiza fungi play an important role in the absorption of nutrients, especially phosphorus by producing phosphatase enzyme which can release bound elements of Phosphorus, Aluminium and Ferrum[7], increasing plant resistance to drought [8], increasing uptake of water and nutrients from the soil [9], increasing uptake of $\mathrm{N}, \mathrm{P}$ and $\mathrm{Ca}$ [10],the plant is able to compete with weeds [11] with improvement the growth and yield of sweet corn [12]. While the provision of organic fertilizer from cow manure can improve soil air and drainage which has an impact on optimal plant root development [13], as a medium for developing and a food source for soil microorganisms or ecosystem engineering, improving soil physical properties, improving soil permeability, adding nutrient, increase the absorption and storage of soil [14].

\section{Material and methods}

\subsection{Study area and experimental design [2]}

This research was conducted in the village of Rambu-Rambu Jaya, Ranomeeto Barat District, South Konawe Regency, Southeast Sulawesi, Indonesia from October to December 2018. The experimental design used in this study used a randomized complete block design (RCBD) in factorial patterns. The first factor is arbuscular mycorrhiza fungi (AMF) consisting of four levels, namely without AMF $\left(\mathrm{A}_{0}\right)$, AMF $5 \mathrm{~g} /$ planting hole $\left(\mathrm{A}_{1}\right)$, AMF $10 \mathrm{~g} / \mathrm{planting}$ hole $\left(\mathrm{A}_{2}\right)$, AMF 15 $\mathrm{g}$ /planting hole (A3). The second factor is cow manure fertilizer (CMF) consisting of three levels, namely without CMF $\left(\mathrm{B}_{0}\right)$, CMF 5 tons ha-1 $\left(\mathrm{B}_{1}\right)$, CMF 10 tons ha-1 $\left(\mathrm{B}_{2}\right)$. The treatment applied consisted of 12 combinations of treatments with 3 replications, so there were 36 experimental units.

\subsection{Preparation of planting area[2]}

The land cleared from weeds or vegetation growing by using a machete, then done soil processing twice. The first step is done by hand tractor ground twice bee loose. After the loose soil, reversing the soil using a hoe and the second step is done by breaking the chunk into a smooth soil condition soil loose. Clearing and raised bed making were manually carried out. Making plot of research done after soil processing, then made a plot with $3 \mathrm{~m} \times 2 \mathrm{~m}$ in size with total 36 plots research, a drainage channel $0.5 \mathrm{~m}$ in size to facilitate the flow of water, so there is no flooding. The maize seeding is done by using manual pit ( 2 seeds per planting holes), spacing as $40 \mathrm{~cm}$ x $70 \mathrm{~cm}$.

\subsection{Aplication of cow manure fertilizer and mycorrhiza fungi[2]}

Application of cow manure is carried out 1 week before planting which is spread evenly above the soil surface. Furthermore, mixing and leveling using a hoe so that fertilizer that has been applied quickly blends and blends with the soil of the experiment. The application of arbuscular mycorrhiza fungi is carried out at the same time as planting sweet corn by inserting it into the planting hole before corn seed.

\subsection{ObservationVariable[3]}

The variables observed in this study were: weight of cob with husk, weight of cobs without husk, length of cobs, diameter of cobs, number of rows of seeds per cob and productivity of sweet corn (tons ha-1).

\subsection{Data analysis [4]}

Data from observations then analyzed using variance, thens continued with the Duncan's Multiple Range Test (DMRT) at $95 \%$ confidence level. 


\section{Results and discussion}

\subsection{Variance recapitulation of plant yield [5]}

The recapitulation of the variance analysis for effect mycorrhiza fungi and cow manure was presented in table 1.

Table 1 Variance recapitulation of arbuscular mycorrhiza fungi and cow manure fertilizer effect on plant yield

\begin{tabular}{|l|l|l|l|l|}
\hline No & Observation variable & AMF (A) & CMF (B) & Interaction (A*B) \\
\hline 1 & Weight of cob with husk & ns & ns & $* *$ \\
\hline 2 & Weight of cobs without husk & ns & ns & $*$ \\
\hline 3 & Length of cobs & ns & ns & ns \\
\hline 4 & Diameter of cobs & ns & ns & ns \\
\hline 5 & Number of rows of seeds per cob & ns & ns & ns \\
\hline 6 & Productivity (ton ha-1) & ns & ns & $*$ \\
\hline
\end{tabular}

Notes: $\mathrm{ns}=$ no significant, ${ }^{*}=$ significant, ${ }^{* *}=$ very significant, $\mathrm{AMF}=$ Arbuscular Mycorrhiza Fungi, CMF = Cow Manure Fertilizer

Table 1 show that the interaction of mycorrhiza fungi and cow manure fertilizer has a very significant effect on the weight of cobwith husk and cobs without husk. Combination treatment of arbuscular mycorrhiza fungi and cow manure fertilizer did not significantly affect to length of cob, the diameter of cob and the number of rows of seed per cob.

\subsection{Weight of cob with husk and cobs without husk [6]}

Table2 Effect of arbuscular mycorrhiza fungi and cow manure fertilizer on the average weight of cob with husk and without husk (g).

\begin{tabular}{|c|c|c|c|c|}
\hline \multirow[b]{2}{*}{$\begin{array}{l}\text { Cow manure fertilizer } \\
\text { (CMF) }\end{array}$} & \multicolumn{4}{|c|}{ Arbuscularmycorrhiza fungi (AMF) } \\
\hline & $\begin{array}{l}\text { Without AMF } \\
\left(A_{0}\right)\end{array}$ & $\begin{array}{l}\text { AMF } 5 \mathrm{~g} / \text { planting } \\
\text { hole }\left(\mathrm{A}_{1}\right)\end{array}$ & $\begin{array}{l}\text { AMF } 10 \mathrm{~g} / \\
\text { planting hole } \\
\left(\mathrm{A}_{2}\right)\end{array}$ & $\begin{array}{l}\text { AMF } 15 g / \\
\text { planting hole } \\
\left(\mathrm{A}_{3}\right)\end{array}$ \\
\hline \multirow[t]{2}{*}{ without $\mathrm{CMF}\left(\mathrm{B}_{0}\right)$} & $180.2 \mathrm{~b}$ & $247.3 \mathrm{a}$ & $289.2 \mathrm{a}$ & $252.5 \mathrm{a}$ \\
\hline & $\mathrm{q}$ & $\mathrm{pq}$ & $\mathrm{p}$ & $\mathrm{p}$ \\
\hline \multirow[t]{2}{*}{ CMF 5 ton ha-1 $\left(B_{1}\right)$} & $337.7 \mathrm{a}$ & $231.3 \mathrm{a}$ & $254.2 \mathrm{a}$ & $233.0 \mathrm{a}$ \\
\hline & $\mathrm{p}$ & $\mathrm{q}$ & q & $\mathrm{q}$ \\
\hline \multirow[t]{2}{*}{ CMF 10 ton ha-1 $\left(B_{2}\right)$} & $241.2 \mathrm{~b}$ & $268.0 \mathrm{a}$ & $267.0 \mathrm{a}$ & $270.3 \mathrm{a}$ \\
\hline & $\mathrm{p}$ & $\mathrm{p}$ & $\mathrm{p}$ & $\mathrm{p}$ \\
\hline DMRT95\% & $2=67.24$ & $3=70.69$ & $4=72.75$ & \\
\hline \multirow[b]{2}{*}{$\begin{array}{l}\text { Cow manure } \\
\text { fertilizer(CMF) }\end{array}$} & \multicolumn{4}{|c|}{ Arbuscularmycorrhiza fungi (AMF) } \\
\hline & $\begin{array}{l}\text { Without AMF } \\
\left(\mathrm{A}_{0}\right)\end{array}$ & $\begin{array}{l}\text { AMF } 5 \mathrm{~g} / \text { planting } \\
\text { hole }\left(\mathrm{A}_{1}\right)\end{array}$ & $\begin{array}{l}\text { AMF } 10 \mathrm{~g} / \\
\text { planting hole }\left(\mathrm{A}_{2}\right)\end{array}$ & $\begin{array}{l}\text { AMF } 15 \mathrm{~g} / \\
\text { planting hole } \\
\left(\mathrm{A}_{3}\right)\end{array}$ \\
\hline \multirow[t]{2}{*}{ without CMF $\left(\mathrm{B}_{0}\right)$} & $130.3 \mathrm{~b}$ & $163.8 \mathrm{a}$ & $208.5 \mathrm{a}$ & $180.8 \mathrm{a}$ \\
\hline & $\mathrm{q}$ & $\mathrm{pq}$ & $\mathrm{p}$ & $\mathrm{p}$ \\
\hline \multirow[t]{2}{*}{ CMF 5 ton ha-1 $\left(B_{1}\right)$} & $238.7 \mathrm{a}$ & $178.8 \mathrm{a}$ & $193.5 \mathrm{a}$ & $171.0 \mathrm{a}$ \\
\hline & $\mathrm{p}$ & $\mathrm{q}$ & $\mathrm{pq}$ & $\mathrm{pq}$ \\
\hline \multirow[t]{2}{*}{ CMF 10 ton ha-1 $\left(B_{2}\right)$} & $173.0 \mathrm{~b}$ & $201.3 \mathrm{a}$ & $192.7 \mathrm{a}$ & $198.5 \mathrm{a}$ \\
\hline & $\mathrm{p}$ & $\mathrm{p}$ & $\mathrm{p}$ & $\mathrm{p}$ \\
\hline DMRT95\% & $2=47.71$ & $3=50.15$ & $4=51.61$ & \\
\hline
\end{tabular}


Table 2 shows that the highest average weighted cob ear was obtained in a combination treatment of mycorrhiza fungi $10 \mathrm{~g} /$ planting hole and without cow manure fertilizer $\left(\mathrm{A}_{2} \mathrm{~B}_{0}\right)$ as $289.2 \mathrm{~g}$, it is not significantly different from with combination treatment of without mycorrhiza fungi and without cow manure fertilizer $\left(\mathrm{A}_{0} \mathrm{~B}_{0}\right)$, combination treatment of mycorrhiza fungi treatment $10 \mathrm{~g}$ /planting hole and cow manure 10 tons ha-1 $\left(\mathrm{A}_{2} \mathrm{~B}_{2}\right)$. This shows that mycorrhiza fungi work more effectively to help plants on less fertile land. The highest average weight of cob without husk obtained in the combination treatment of without mycorrhiza fungi and cow manure 5 tons ha- ${ }^{-1}\left(\mathrm{~A}_{0} \mathrm{~B}_{1}\right)$ as $238.7 \mathrm{~g}$, it was significantly different from the combination treatment of without mycorrhiza fungi and without cow manure $\left(\mathrm{A}_{0} \mathrm{~B}_{0}\right)$ and combination treatment of without mycorrhiza fungi and cow manure 10 tons ha ${ }^{-1}\left(\mathrm{~A}_{0} \mathrm{~B}_{2}\right)$. Heike et al.[15], the majority of these mycorrhiza interactions is mutually beneficial for both partners and is characterized by a bidirectional exchange of resources across the mycorrhiza interface. The mycorrhiza fungus provides the host plant with nutrients, such as phosphate and nitrogen, and increases the abiotic (drought, salinity, heavy metals) and biotic (root pathogens) stress resistance of the host. In addition, mycorrhiza fungi can protect plants from drought maintain soil aggregate stability in the presence of hyphae threads that continue to develop in the soil.

\subsection{Productivity of Sweet corn (ton ha-1) [7]}

The interaction of cow manure fertilizer and mycorrhiza fungi significantly affects to productivity of sweet corn plants(table 3).

Table 3 Impact of interaction arbuscular mycorrhiza fungi and cow manure fertilizer on the average productivity of sweet corn (ton ha-1).

\begin{tabular}{|c|c|c|c|c|}
\hline \multirow{2}{*}{$\begin{array}{l}\text { Cow manure fertilizer } \\
\text { (CMF) }\end{array}$} & \multicolumn{4}{|c|}{ Arbuscular mycorrhiza fungi (AMF) } \\
\hline & $\begin{array}{l}\text { Without AMF } \\
\left(\mathbf{A}_{0}\right)\end{array}$ & $\begin{array}{lr}\text { AMF } 5 & \text { g/ } \\
\text { planting } & \text { hole } \\
\left(A_{1}\right) & \end{array}$ & $\begin{array}{l}\text { AMF } 10 \mathrm{~g} / \\
\text { planting hole } \\
\left(\mathrm{A}_{2}\right)\end{array}$ & $\begin{array}{l}\text { AMF } 15 \mathrm{~g} / \\
\text { planting hole } \\
\left(\mathrm{A}_{3}\right)\end{array}$ \\
\hline \multirow[t]{2}{*}{ without CMF $\left(\mathrm{B}_{0}\right)$} & $4.65 \mathrm{~b}$ & $5.85 \mathrm{a}$ & $7.45 \mathrm{a}$ & $6.46 \mathrm{a}$ \\
\hline & $\mathrm{q}$ & $\mathrm{pq}$ & $\mathrm{p}$ & $\mathrm{p}$ \\
\hline \multirow[t]{2}{*}{ CMF 5 ton ha-1 $\left(B_{1}\right)$} & $337.7 \mathrm{a}$ & $6.39 \mathrm{a}$ & $6.91 \mathrm{a}$ & $6.11 \mathrm{a}$ \\
\hline & $\mathrm{p}$ & $\mathrm{q}$ & $\mathrm{pq}$ & $\mathrm{pq}$ \\
\hline \multirow[t]{2}{*}{ CMF 10 ton ha-1 $\left(B_{2}\right)$} & $337.7 \mathrm{a}$ & $7.19 \mathrm{a}$ & $6.88 \mathrm{a}$ & $7.09 \mathrm{a}$ \\
\hline & $\mathrm{p}$ & $\mathrm{p}$ & $\mathrm{p}$ & $\mathrm{p}$ \\
\hline DMRT 95\% & $2=1.70$ & $3=1.79$ & $4=1.84$ & \\
\hline
\end{tabular}

Notes: the numbers followed by unequal letters in the same row (ab) and column (pq) differ significantly with Duncan Multiple Range Test (DMRT) at $95 \%$ confidence level.

Table 3 shows that the highest average corn productivity was obtained in a combination of treatment without mycorrhiza fungi and cow manure 5 tons ha-1 $\left(\mathrm{A}_{0} \mathrm{~B}_{1}\right)$ as 8.52 tons ha-1 which was significantly different from without mycorrhiza fungi and cow manure $\left(\mathrm{A}_{0} \mathrm{~B}_{0}\right)$ and without mycorrhiza fungi and cow manure 10 tons ha-1 $\left(\mathrm{A}_{0} \mathrm{~B}_{2}\right)$. The high yield of treatment without mycorrhiza fungi is suspected in the study area there are many kinds of local mycorrhiza fungi, where the vegetation that grows before land management is Imperata cylindrica. This is supported by Halim [11], that in rooting of I.cylindrica are found mycorrhiza fungi such as Gigaspora sp, Glomus sp and Acalauspora sp with different spore densities.

\section{Conclusion}

Based on the results of the study it can be concluded that the highest average weighted of cob was obtained in combination treatment of arbuscular mycorrhiza fungi $10 \mathrm{~g} /$ planting hole and without cow manure fertilizer $\left(\mathrm{A}_{2} \mathrm{~B}_{0}\right) \mathrm{as}$ $289.2 \mathrm{~g}$. The highest productivity of sweet corn was obtained in the combination treatment of without mycorrhiza fungi and cow manure 5 tons ha-1 $\left(\mathrm{A}_{0} \mathrm{~B}_{1}\right)$ as 8.52 tons ha-1. 


\section{Compliance with ethical standards}

\section{Acknowledgments}

The author would like to thank to the Ministry of Research, Technology and Higher Education of the Republic of Indonesia for the financial assistance through the scheme ofApplieds Research in 2018.

\section{Disclosure of conflict of interest}

Halim and Fransiscus Suramas Rembon were designed and performed the experiments and also wrote the manuscript. Laode Sabaruddin, Yulius Bara Pasolon and Sahta Ginting were reviewed the manuscript. La Ode Santiadji Bande was collected the data, analyzed and interpreted the data. All authors read and approved the final version. The authors declared that present study was performed in absence of any conflict of interest.

\section{References}

[1] Li C, Boyhan G, Sumner P. Commercial sweet corn production in Georgia. Bulletin 1388. University of Georgia Cooperative Extension, in Seminis"Sweet corn growth stages and GDUs-Agronomic Spotlight. 2011.

[2] Nuryadin AK, Suprapti E, Budiyono A. The effect of planting time and dose fertilizer NPK on growth and yield of sweet corn (Zea mays Saccharata (Sturt.). AGRINECAm. 2016; (16)2: 12-23.

[3] Kumar RS, Kumar B, Kaul J, Karjagi CG, Jat SL, Parihar CM and Kumar A. Maize research in India-historical prospective and future challenges. Maize Journal. 2016; 1(1): 1-6.

[4] Siyuan S, Tong Li, RuiHai Liu. Corn phytochemicals and their health benefits. Food Science and Human Wellness. 2018; 7: 185-195.

[5] Bakrie AH. Respon Tanaman Jagung Manis (Zea mays Saccharata) Varietas Super Sweet terhadap Penggunaan Mulsa dan Pemberian Kalium. Prosiding Seminar Nasional Sains dan Tekhnologi II 2008. Universitas Lampung. Lampung. Indonesia. 2006.

[6] Granados G, Pandey S, Ceballos H. Response to selection for tolerance to acid soils in tropical maize population. Crop Sci. 1993; 26(2): 253-260.

[7] Marschner H, Dell B. Nutrient uptake in mycorrhiza symbiosis. Plant Soil. 1994; 159: 89-102.

[8] Auge RM,Stadola AJW. An Apparent Increase in Symplastic in Water Contributes to Greater Turgor in Mycorrhizal Roots of Droughted Rosa Plants. New Pytol. 1990; 115: 285-295.

[9] Halim, Makmur JA, Fransiscus SR, Resman. Impact of mycorrhiza fungi from grassland rhizosphere and liquid organic fertilizer to the growth and yield of sweet corn on ultisols in South Konawe, Indonesia. Agriculture, Forestry and Fisheries. 2015; 4(5): 209-215.

[10] Delvian. The use of humic acid in arbuscular mycorrhizal fungi of high salinity ecosystem. Jurnal Ilmu-Ilmu Pertanian Indonesia. 2007; 9(2): 124-129.

[11] Halim. The role of endomycorrhiza indigenous of Imperata cylindrica (L.) Beauv and Eupatorium odorata (L.) in weed and corn competitive. Dissertation (Unpublished). Graduate Programe of Padjadjaran University Bandung. Indonesia.2009.

[12] Halim, TC Rakian, Sarawa, Muhidin, A Madiki, M Tufaila, Resman, WSA Hisein,Aminuddin MK. Weed density, growth and yield of sweet corn (Zea mays Saccharata (Sturt.) Bailey) after treatment with mycorrhiza fungi on marginal dry land. Bioscience Research. 2018; 15(1): 466-473.

[13] Simanjuntak NC, Bayu ES, Nuriadi I. Paclobutrazol Application Study on Balance the Growth of Three Varieties of Peanuts (Arachis hypogaea L.). Jurnal Agroteknologi. 2013; 2(1): 279-287.

[14] Arifin Z. Bokashi (Bahan Organik Kaya Sumber Hidup). Balai Teknologi Pertanian UPTD Pertanian. Malang. Indonesia.2007.

[15] Heike B, Elliot L, Prashant A. The Role of the Mycorrhizal Symbiosis in Nutrient Uptake of Plants and the Regulatory Mechanisms Underlying These Transport Processes. Book Chapter (4) in Plant Science. 2012; 108138. 